Article

\title{
Geosites for Geotourism, Geoheritage, and Geoconservation of the Khnefiss National Park, Southern Morocco
}

\author{
Saïd Mirari ${ }^{1, *(\mathbb{D}}$, Ali Aoulad-Sidi-Mhend ${ }^{2}$ and Abdelouahed Benmlih ${ }^{1}$ \\ 1 Laboratory of Tourism Engineering, Heritage and Sustainable Development of the Territories, Faculty of \\ Science in Rabat, Mohammed V University, Rabat P.O. BOX 1014, Morocco; benmlihabdelouahed@yahoo.fr \\ 2 Laboratory of Natural Resources Geosciences, Department of Geology, Faculty of Science in Kenitra, \\ Ibn Tofail University, Kenitra, P.O. BOX 14060, Morocco; saadmhend@gmail.com \\ * Correspondence: mirarisaid@gmail.com
}

Received: 2 July 2020; Accepted: 17 August 2020; Published: 31 August 2020

check for updates

\begin{abstract}
Khnefiss National Park has a very unique advantage of presenting three landscape morphologies of high quality: the coastal band, where the sea, dunes and cliffs mix; the lagoon zone, with its multiple interlacing water, algae and sand; and the vast desert, with its regs, hamadas, krebs, and dune extensions. It is unique and original at the world level for a protected area to retain in a single perimeter these three major ecosystems, which therefore gives this national park an exceptional quality. Khnefiss national park faces numerous natural, human-induced, institutional, organizational, and legal constraints. Hence, there is a need for a practical tool that would reconcile the imperatives of conservation, the demands of the local population, and tourism, and at the same time positively address the constraints that hamper the management of this geosite. Indeed, we will highlight a reflection that aims at clarifying the sense of this new trajectory in which Morocco is positioned in terms of interest development of geological heritage, the emergence of consumption of natural assets, and potentialities phenomenon according to regions. Therefore, all actions are based on values of citizenship, participative, responsibility, ethicality, and fairness. Indeed, the geosites have small to large scale characteristics (from ten meters to more than $10 \mathrm{~km}$ ). The geosite inventory is based on the geoconservation strategy. Qualitative and quantitative assessments were carried out on the basis of geoheritage values of international significance. Thene, geoconservation efforts should be made in all these geosites for many reasons, such as valorization of academic research, preservation of natural resources, and promotion of geotourism in Khnefiss national park.
\end{abstract}

Keywords: geoheritage; geotourism; geosites; geoconservation and Khnefiss national park

\section{Introduction}

Morocco has adopted a new approach to development that integrates the environmental component, the rationalisation of natural resources, the measures of poverty reduction, and the appropriate social and spatial distribution of wealth according to an advanced regionalisation plan [1].

The issue of geotourism has become a recent and pressing concept in the government's 2020 vision for tourism as it has recently been demonstrated that it represents a real factor of sustainable development [2]. As it is a form of tourism that responds to a strong demand, it is taken into consideration by decision-makers and stakeholders in the tourism industry and in the strategic programmes and plans implemented [3]. Tourist activities have a direct impact on both local population and natural landscape; a better match between men and biosphere has a good synchronization according to the tourist context and the offer of specific products to each region. 
Khnefiss national park has the outstanding advantage of having three very high quality landscape morphologies: the coastal strip, with a mixture of seabed, dunes, and coastal cliffs; the lagoon area with its multiple interlacing of water, algae, and sand; and the desert vastness with the regs, hamadas, Krebs, and dune extensions [4].

This park has a real economic and sociocultural attractiveness due to its geographical position and its important natural resources related to the structural geological domain. It therefore constitutes a sector of undeniable tourist value and an important tourist destination according to its specialization in the territorial offer and thanks to the particularity and specificities of its goods and services related to the geotourism activity that could arise. The identification of geological heritage values $[5,6]$ constitutes the first principle in the elaboration of geotourism circuits and the basis for promoting the revitalisation of rural areas through new tourism opportunities.

This orientation is reflected in the initiation of a broad debate within society on the subject of geotourism, geoheritage, and geoconservation [7-10]; in a world of increased industrialization, the environmental issues have been omitted [11]. The need to preserve the ecological and geological [12] space is a major concern in an economic context that promotes the integration of alternative tourism in the new philosophy of the national strategy in the tourism sector [13].

\section{Study Area}

Khnefiss national park is located $200 \mathrm{~km}$ from the city of Laayoune to the South. In view of the ecological interest of other parts surrounding the Site of Biological and Ecological Interest (SBEI), extension proposals have been made to encompass coastal, marine, lagoon, dune, and Saharan ecosystems [14]. It was officially declared by a ministerial decree as a national park on 26 September 2006, and it covers an area of 185,000 ha (Figure 1).
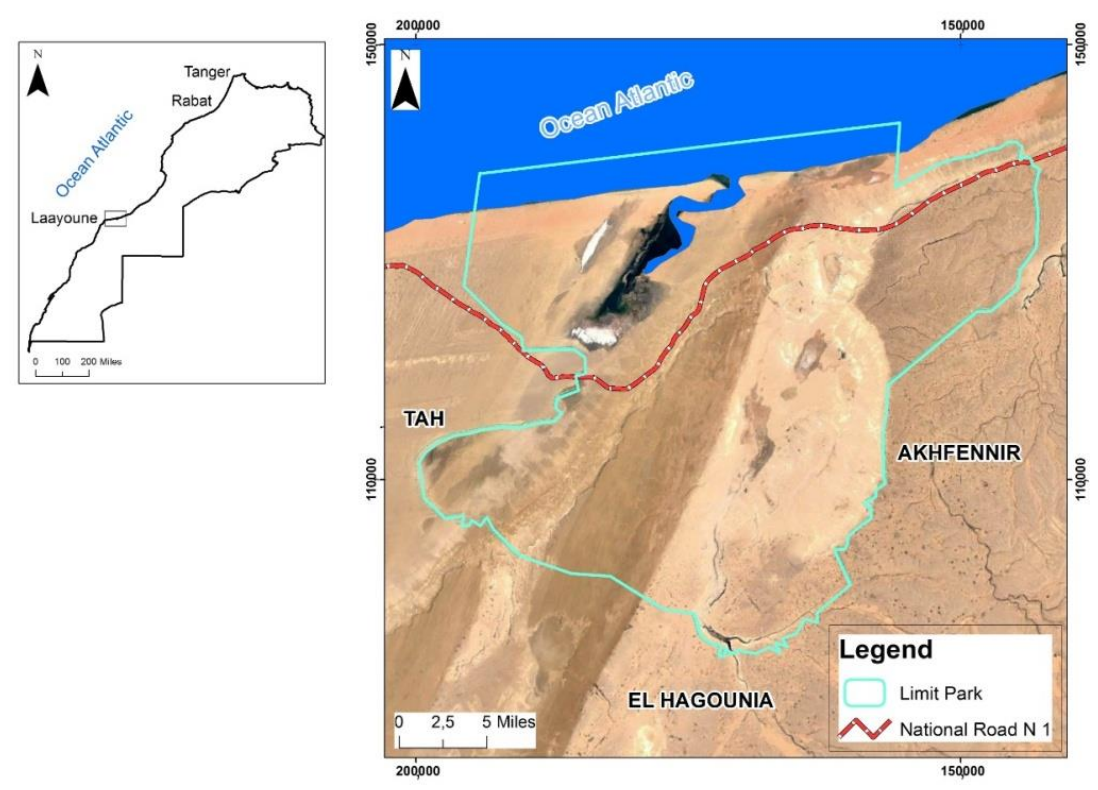

Figure 1. Location of the study area "Knefiss National Park".

In addition, the park presents quite remarkable landscapes with a truly unique ecological quality. It is distinguished by two major physiographic elements [4]: the coastal zone with its lagoon, which is the living heart and founder of the biological richness of the site and the vast inland hamadas dotted with reliefs, plateaus, Krebs (typical cliffs (escarpment) of the arid zone. It offers sections showing the complexity of the hamada's geological formations and the rapid facies variations typical of continental deposits [15]), dunes, and some valleys of the wadi. 
The Naila lagoon is an inlet, which runs deep inland for more than $20 \mathrm{~km}$, forming a vast wetland enclosed between sharp dunes and small sandstone cliffs [16]. It is located on the Atlantic Coast, between the city of Tantan and that of Tarfaya. It is the largest atlantic lagoon in Morocco $\left(65 \mathrm{~km}^{2}\right)$. It extends from a huge salt depression (Tazgha salt flats) on the south to sand dunes of Akhfennir, as it can be flooded during high tides [17]. There is also a powerful contrast between the surrounding desert immensities, single-coloured and desolate, and the sheer vastness of the wetland, teeming with life, colour, and movement [17].

The seafront along this coast is narrow, bounded almost everywhere by sharp cliffs, which leave little room for the beach [18]. The contact with the ocean is always turbulent, as the flow on this relatively powerful coastal façade is strong with transverse currents [19]. Thus, the coastline is strongly impregnated with wilderness, where one finds a totally free foreshore over kilometres and sometimes impetuous waves hitting high, steep, and inhospitable cliffs [16].

The desert area surrounding the lagoon extends over the vast continental shelf that occupies this entire portion of coastal occidental Sahara. Sandstone masses largely predominate over the sandy mounds [19], distributed between large regs, whose flat topography rises slightly to the interior reliefs, made up of tabular escarpments that are more or less carved and separated by depressed areas either filled by sand or occupied by immense Sebkhass [16]. The highest cliffs do not exceed $200 \mathrm{~m}$, with the elevation increasing inland [20]. Its strategic geographical position at the gateway to the Sahara, its particular climatic conditions, the richness of its vegetation, and the presence of diversified and original habitats have favoured the establishment of settlements of different biogeographical origins [5].

The region is part of the coastal basins that mark the flexure between Paleozoic structures and the coast. The lithostratigraphic setting of the region is masked by neogene cover at the level of the atlantic plain, which varies slightly between north and south as far as the town of Dakhla [21]. The deposition of the prograding series is well expressed in the distal part of the immense coastal basin of Tarfaya [22]. The formations show interlocking levels from the mid-Pliocene to the marine quaternary. With this drilling data, the dominant formations are as follows:

- Secondary formations of marl, sandstone, and limestone from the upper Jurassic to the upper Cretaceous. The latter occupy almost the entire basin of the Khaoui Naàm Wadi and the lower El Waer Wadi. The cornice escarpments (Kreb) constitute the limits between this formation and that of the limestones of the hamada (plateau) [23].

- A Plio-Quaternary limestone formation of the Pliocene hamada. This formation occupies the entire interior of the area known as Gaada (plateau) [24].

- The Moghrebian sandstones and limestones of the coastal platform. This area extends from the coast and stops at the level of the inland cliffs [25].

- The dunes consolidated in sandstone of the ancient Quaternary age ranges. This formation includes deposits in the form of hydraulic dunes of progradation whose thicknesses vary between 5 and 20 metres. This formation exists only locally along the coast near the outlet of the El Waer Wadi [4].

- The sharp cliffs of the recent Quaternary, which are linked to the current coastal dynamics. These are dunes that sometimes evolve into small barkhan dunes whose orientation is NE. These morphological units are located in the Naila zone [4].

Geotourism: The proximity of Khnefiss national park to the major tourist centres and its location in a region with strong natural potential makes this site an excellent place of attraction for the region. It is a natural site that contrasts with the Saharan and Anti-Atlasic landscape. Added to the palette of resources of the southern Moroccan domain, it will be able to enrich its offers with an exceptional geotouristic product. The geotourism activity in this park takes in its entire dimension in terms of:

- A destination with a strongly contrasted, diversified and singular biogeographical richness in the Saharan provinces of south-west Morocco in direct transition with the Atlantic coast; 
- A territory with a landscape as well as a archaeological, cultural and historical heritage to be promoted.

- Traditions and the lifestyle of nomadic people practising transhumance in a particular Saharan region where the populations have adapted to fishing, breeding, and handcrafts. A way of life in harmony between the local population and its natural environment.

\section{Materials and Methods}

For the elaboration of this article, a set of materials are used, including literature, maps, and photographs related to the Knefiss national park. The methodology used in this work is the inventory, characterization, classification, evaluation and valorization of geosites and geodiversity. The inventory was carried out through the identification, distribution, and evaluation of the most important sites in the park based on a geological and biological survey. The survey was elaborated by reading literature reviews, fieldworks, and interviews with local geological heritage specialists.

The characteristics of geosites and geodiversity have been based on direct observation, relevant selection, detailed description, and quantitative assessment through the work of $[6,26]$, as well as based on other previous researches $[27,28]$. The assessment of geosites and geodiversity sites consists of four distinct parts with different criteria and valued by five components. In this assessment, there is no ranking since the parts are evaluated and presented separately [6,29].

Field exploration data provide information on the location and range validation of geosites that exist in the study area. Baseline data were obtained from studies elaborated by multidisciplinary reports, composed of public institutions and scientific and academic research on the basis of Scopus, Google Scholar, MDPI, and ResearchGate databases. The results of this literature review (biological, ecological, and geological) were used to evaluate the additional data to be collected in the field from September to December 2019. Field data were collected from direct interviews with the specific administrative departments, local population, tourists on a random basis and direct observations of the selected geosites.

Two evaluation approaches are adopted for the development of this article: a qualitative approach, which gives particular attention to the geographic and geological heritage values for classification and description, and a quantitative approach, which aims to assess the geosites and their geoheritage value to establish development strategies. The evaluation of geosites and geodiversity sites consists of four parts with different criteria for each component: Scientific Value (SV), Potential Educational Use (PEU), Potential Tourism Use (PTU), and Risk of Degradation (DR). The number of criteria in the quantitative assessment, which should be limited as a high number, does not necessarily imply a more relevant and effective result. In this assessment, there is no final ranking as the parties are assessed and presented separately $[6,30]$. Data collected may be easily rectified and improved according to site changes or land use plans [31,32].

Scientific value (SV) is valued by seven criteria: Representativeness (R), key locality (Kl), scientific knowledge (Sn), integrity (I), geological diversity (Gd), rarity (R), and limits of use (Ul). Each criterion is punctuated by the values $0,1,2$, and 4 (value 3 is not used) and is also weighted by percentage (Table 1) [6]. The Potential Educational Use (PEU) is valorised with 12 criteria based on the vulnerability $(\mathrm{V})$, accessibility (A), use limitations (Ul), safety (S), logistics (L), density of population (Dp), associations with other values $(\mathrm{Av})$, scenery $(\mathrm{Sc})$, uniqueness $(\mathrm{U})$, observation conditions (Oc), didactic potential $(\mathrm{Dp})$, and geological diversity $(\mathrm{Gd})$. In this case, vulnerability $(\mathrm{V})$ is understood as the existence of elements of geodiversity that can be destroyed by visitors $[6,33]$. Each criterion is punctuated with values 0 to 4 and also weighted according to percentage (Table 1). The Potential Touristic Use (PTU) is valorised with 13 criteria. Eight of these criteria are equal to those used in the PEU (V, A, Ul, S, L, $\mathrm{Dp}, \mathrm{Av}, \mathrm{Sc}, \mathrm{U}, \mathrm{Oc}$ ) in addition to three new criteria: Interpretative potential (Ip), economical level (El), and proximity to recreational areas (Pr). In the same way as the PEU, each criterion is punctuated by values 0 to 4 and also weighted according to percentage (Table 1). The concept of Degradation Risk (DR) is a combination of other factors such as accessibility, size, proximity to human settlements, 
public influx, and current or potential threats [34]. In this research, evaluation using five criteria [6] is based on the deterioration of geological elements (Dg), proximity of activities to a potential cause of degradation $(\mathrm{Pa})$, legal protection ( $\mathrm{Lp}$ ), accessibility (Ac), and density of population (Dpp). Each criterion is punctuated by values 0 to 4 and also weighted by percentage (Table 1 ). In the case of the DR, Ac and Dpp criteria are similar to those used in the PEU and PTU but here, they are used in a negative sense [26].

Table 1. General framework of the evaluation of geosites Brilha (2016).

\begin{tabular}{|c|c|c|}
\hline Parts & Criteria (Scored 0 to 4 ) & Weighting (\%) \\
\hline \multirow{7}{*}{ Scientific Value (SV) } & Representativeness (R) & 30 \\
\hline & Key locality (Kl) & 20 \\
\hline & Scientific knowledge (Sn) & 5 \\
\hline & Integrity (I) & 15 \\
\hline & Geological diversity (Gd) & 5 \\
\hline & Rarity (R) & 15 \\
\hline & Use limitations (UI) & 10 \\
\hline \multirow{12}{*}{ Potential Educational Use (PEU) } & Vulnerability (V) & 10 \\
\hline & Accessibility (A) & 10 \\
\hline & Use limitations (Ul) & 5 \\
\hline & Safety (S) & 10 \\
\hline & Logistics (L) & 5 \\
\hline & Density of population (Dp) & 5 \\
\hline & Associations with other values (Av) & 5 \\
\hline & Scenery (Sc) & 5 \\
\hline & Uniqueness (U) & 5 \\
\hline & Observation conditions (Oc) & 10 \\
\hline & Didactic potential (Dp) & 20 \\
\hline & Geological diversity (Gd) & 10 \\
\hline \multirow{13}{*}{ Potential Touristic Use (PTU) } & Vulnerability (V) & 10 \\
\hline & Accessibility (A) & 10 \\
\hline & Use limitations (Ul) & 5 \\
\hline & Safety (S) & 10 \\
\hline & Logistics (L) & 5 \\
\hline & Density of population (Dp) & 5 \\
\hline & Associations with other values (Av) & 5 \\
\hline & Scenery (Sc) & 15 \\
\hline & Uniqueness (U) & 10 \\
\hline & Observation conditions (Oc) & 5 \\
\hline & Interpretative potential (Ip) & 10 \\
\hline & Economic level (El) & 5 \\
\hline & Proximity recreational areas $(\mathrm{Pr})$ & 5 \\
\hline \multirow{5}{*}{ Degradation Risk (DR) } & Deterioration geological elements (Dg) & 35 \\
\hline & Proximity activities cause of degradation (Pa) & 20 \\
\hline & Legal protection (Lp) & 20 \\
\hline & Accessibility (Ac) & 15 \\
\hline & Density of population (Dpp) & 10 \\
\hline
\end{tabular}

The thresholds used in each part of the valorisation are: 0-25 low, 26-50 moderate, 51-75 high, and 76-100 very high. In this research, when a site of geological interest reaches an SV value greater than 75, it is considered a geosite (GS). Similarly, when a site of geological interest reaches a value in the PEU or PTV greater than 75, it is considered to be a site of geodiversity. In the case of very high values in SV but also in PEU and/or PTU, the term geosite has prevailed, although the site may also be used as a geodiversity site for educational and tourism purposes.

\section{Results}

The site is located in the northern part of the "Tarfaya-Laayoune Coastal Basin" (Figure 2), bordered to the North by the Anti-Atlas, to the South by the Mauritanide Belt and to the East by the dorsale of Reguibat. This basin consists of a Precambrian-age basement, outcropping at the level of the 
Saharan hinterland, and a coastal meso-Cenozoic sedimentary cover (Miocene sands surmounted by a Quaternary Moghrebian sands) consisting of calcareous sandstone. The thickness of the Quaternary "platform", where the Khnefiss site is excavated, reaches several metres (up to $40 \mathrm{~m}$ ) [25] (Figure 3). The sites of Khnefiss national park are given below and run along the national road $\mathrm{N}^{\circ} 1$ coming from the North towards the South.
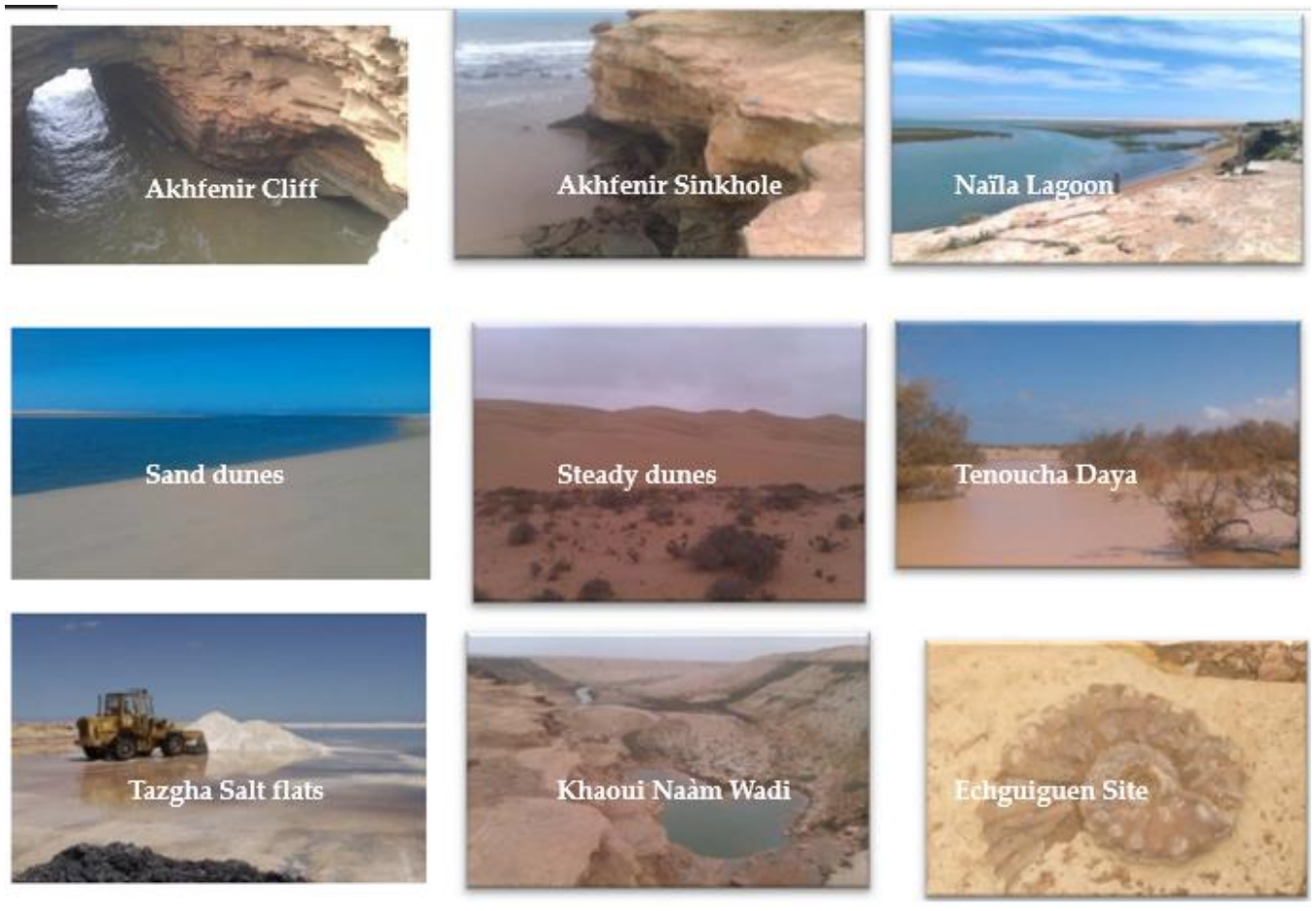

Figure 2. Geosites selected in The Khnefiss National Park.

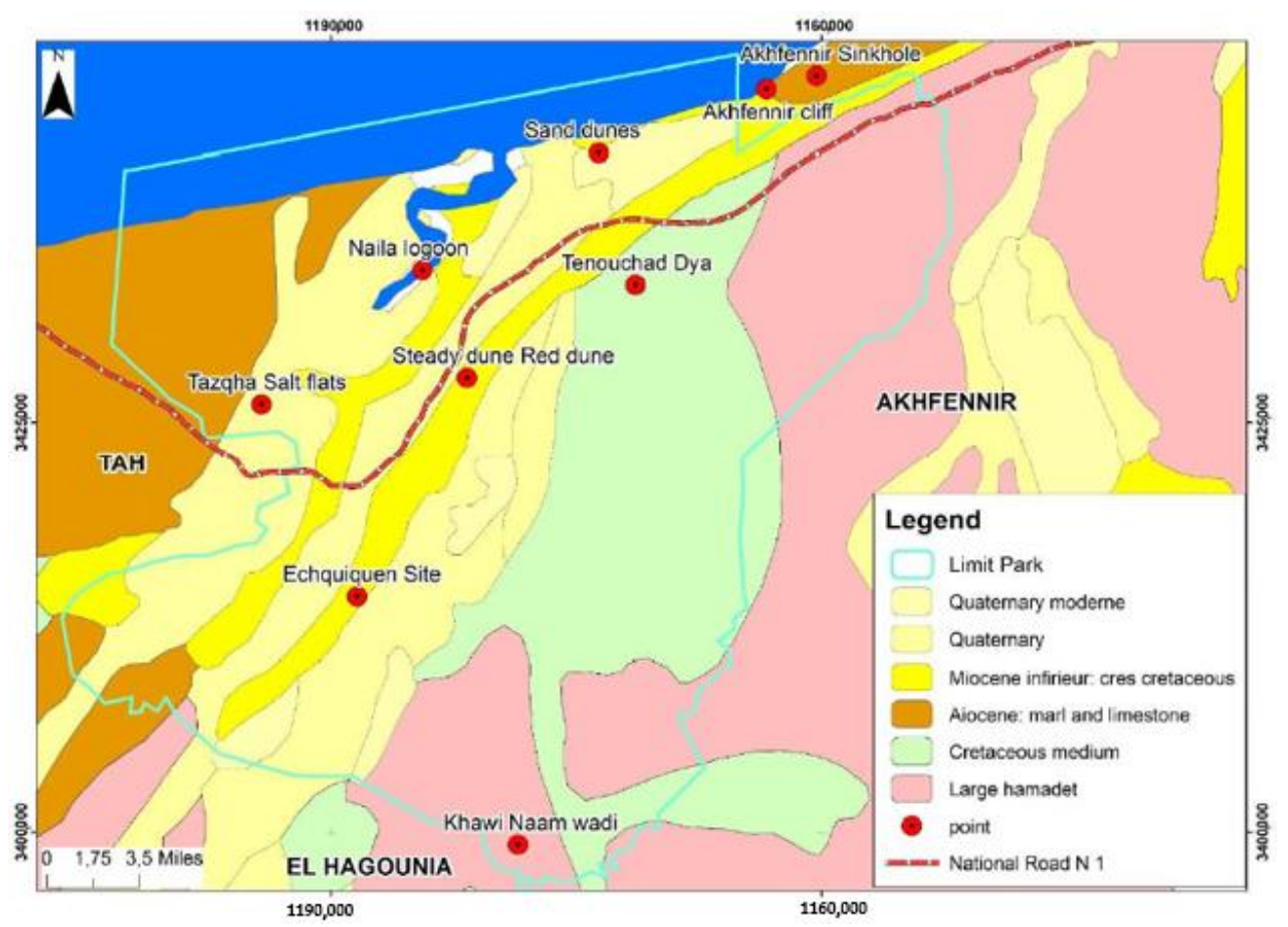

Figure 3. Geological card of selected geosites in Khnefiss National Park. 


\section{Akhfennir sinkhole}

Locally called "Aàjb Allah", and sometimes called the "devil's hole", this abyss, about $30 \mathrm{~m}$ deep, is both a natural curiosity and a real risk for accidents. It is a few dozen meters from the roadside.

\section{Akhfenir cliff}

The entire coast is overhung by steep cliffs over $50 \mathrm{~m}$ in height and then stops to give way for sandy beaches. This site, therefore, has a double attraction, ornithological and for artisanal fishing.

\section{Naila lagoon}

The bay (or lagoon) is in the form of a long inlet cut into a sandstone limestone plateau (Moghrebian) resting on marls (cretaceous), in the form of a sinuous channel leading to a vast salt depression $[4,35]$. A string of vivid sandy dunes, interspersed between the lagoon and the ocean, causes a narrowing of the channel and extends southwards along the western shore of the lagoon [36,37]. The lagoon is dominated to East and South by a long cliff, 25 to $35 \mathrm{~m}$ high, cut into the rocky plateau [4]. The channel, known as "Foum Agwitir", is about $100 \mathrm{~m}$ wide and 5-6 m deep, ensuring the circulation of a large volume of water; the hydrology of the lagoon is thus almost exclusively determined by the tide gauge rhythm $[15,37]$. The marine water penetrates the mainland through a wide channel, which gradually narrows towards the south and then splits into several small narrow channels that flow between a formation of halophytes. This water flow is accompanied by strong hydrodynamics, particularly in the northern half of the lagoon $[19,20]$.

\section{Sand dune}

From the cliff to the lagoon of Naila extends a cordon of living dunes all along the coast, surrounding certain large beaches, and thus, creating favourable aesthetics for potential seaside tourists, while also constituting the privileged habitat of specific fauna, in particular the "fennec" or sand fox [38].

\section{Steady dunes}

In addition to the numerous dune cords formed by living dunes, there are two fixed and stabilized dunes, which the locals call the red dunes and the twin dunes [16]. These dunes take on a bright red colour at certain times of the day, depending on the angle of exposure to the sun.

\section{Tenouchad daya}

Dayas (Daïa) are low-amplitude depressions that, in the endorheic regions of the Maghreb, dot the rigid surface of plateaus protected by lacustrine limestone or soil crust [39]. Tenouchad is a daya of about 10 hectares located in the middle of the desert zone in the Khnefiss national park. When arriving on the plateau, the pink dunes are detectable on the horizon; the daya, hidden beyond the southern edge of the plateau, is marked by the tops of its tamarisk trees [40].

\section{Tazgha salt flats}

The Nailla lagoon extends inland into a huge salt depression, the Sebkhas of Tazgha, glowing white in the middle of the surrounding reddish-brown lands. During the highest tides, seawater overflows southwards and spreads out over the vast salt plain of Tazgha Salt flats, which dries out quickly under the effect of insolation and constitutes a salt accumulation field, which is exploited (The saltworks (geosite) of Sebkhat Tazgha is a public domain (Order of 1914; BO: 10/7/1914, page 529), managed by the Ministry of Equipment and Public Works. Its exploitation is governed by the Dahir of 30 November 1918, relating to temporary occupation (BO: 20/1/1919, page 37)). Without recourse to any kind of development [41].

\section{Khaoui Naàm Wadi}

The Khaoui Naam waterfall is one of the remarkable sites of the Khnefiss national park and deserves a day trip, but it is only accessible to all-terrain vehicles. In its upstream part, the wadi and its micro-effluents have deeply cut the plateau into multiple ramifications, but the valleys are still quite wide. The wadi has narrowed and formed a magnificent waterfall several tens of metres high, which is totally unexpected in this desert environment. Downstream of the waterfall, a first Guelta of about ten meters long flows into a second one, which in turn flows down in a series of cascades into the wadi surrounded by rocks and halophilic plants [4]. 


\section{Echguiguen site}

A few hundred meters south of the red dunes rises the Echgiguen plateau. Dotted with tumulus, this plateau is bordered by a long paved alley of about five hundred meters, which some authors attribute to the remains of a road or a wall, even making reference to a city built nearly two millennia ago [42].

Nine sites are located along the main road to southern Morocco. These assessments were also quantified using the Brilha (2016) methodology adapted to our valuation (Table 2), as the results show in Figure 4. The quantitative and qualitative evaluations are shown successively in the following tables: Table 3 for the Scientific Value (DV), Table 4 for the Potential Educational Use (PEU), Table 5 for the Potential Touristic Use (PTU), and Table 6 for the Degradation Risk (DR). Moreover, the result of the evaluation is developed in Table 7 as a quantitative summary.

Table 2. Sites of geological interest (Geosites and Geodiversity sites).

\begin{tabular}{|c|c|c|c|c|c|}
\hline $\begin{array}{c}\text { Site } \\
\text { Nombre }\end{array}$ & Site Name & $\begin{array}{l}\text { Commune/ } \\
\text { Toponymie }\end{array}$ & Site Code & Site Type & $\begin{array}{l}\text { Coordon } \\
\text { GPS }\end{array}$ \\
\hline 1 & Akhfennir Sinkhole & Akhfennir & AS & Speleology & $\begin{array}{l}28^{\circ} 10^{\prime} \mathrm{N} \\
12^{\circ} 03^{\prime} \mathrm{W}\end{array}$ \\
\hline 2 & Akhfénir Cliff & Akhfennir & $\mathrm{AC}$ & Geomorphology & $\begin{array}{l}28^{\circ} 09^{\prime} \mathrm{N} \\
12^{\circ} 04^{\prime} \mathrm{W}\end{array}$ \\
\hline 3 & Naïla Lagoon & Akhfennir & NL & Hydrogeology & $\begin{array}{l}28^{\circ} 03^{\prime} \mathrm{N} \\
12^{\circ} 16^{\prime} \mathrm{W}\end{array}$ \\
\hline 4 & Sand Dunes & Akhfennir & SD & Geomorphology & $\begin{array}{l}28^{\circ} 09^{\prime} \mathrm{N} \\
12^{\circ} 06^{\prime} \mathrm{W}\end{array}$ \\
\hline 5 & Steady Dunes & Akhfennir & STD & Geomorphology & $\begin{array}{l}28^{\circ} 03^{\prime} \mathrm{N} \\
12^{\circ} 16^{\prime} \mathrm{W}\end{array}$ \\
\hline 6 & Tenouchad Daya & Akhfennir & TD & Hydrology & $\begin{array}{l}28^{\circ} 04^{\prime} \mathrm{N} \\
12^{\circ} 07^{\prime} \mathrm{W}\end{array}$ \\
\hline 7 & Tazgha Salt Flats & Akhfennir & TSF & Mineralogy & $\begin{array}{l}27^{\circ} 54^{\prime} \mathrm{N} \\
12^{\circ} 20^{\prime} \mathrm{W}\end{array}$ \\
\hline 8 & Khaoui Naàm Wadi & Akhfennir & KNW & Hydrogeology & $\begin{array}{l}27^{\circ} 40^{\prime} \mathrm{N} \\
12^{\circ} 13^{\prime} \mathrm{W}\end{array}$ \\
\hline 9 & Echguiguen Site & Akhfennir & ES & Archaeology & $\begin{array}{l}27^{\circ} 98^{\prime} \mathrm{N} \\
12^{\circ} 16^{\prime} \mathrm{W}\end{array}$ \\
\hline
\end{tabular}

Table 3. Recommendations and advice for each category of Scientific Value (SV).

\begin{tabular}{cccccccccc}
\hline Site-Nombre & Site Code & SV & $\mathbf{( R )}$ & $\mathbf{( K I )}$ & $\mathbf{( S n )}$ & $\mathbf{( I )}$ & $\mathbf{( G d )}$ & $\mathbf{( R )}$ & (UI) \\
\hline 1 & AS & 78.8 & 30.0 & 10.0 & 1.3 & 15.0 & 5.0 & 7.5 & 10.0 \\
2 & AC & 78.8 & 30.0 & 10.0 & 1.3 & 7.5 & 5.0 & 15.0 & 10.0 \\
3 & NL & 80.0 & 30.0 & 10.0 & 2.5 & 7.5 & 5.0 & 15.0 & 10.0 \\
4 & SD & 72.5 & 30.0 & 10.0 & 2.5 & 7.5 & 5.0 & 7.5 & 10.0 \\
5 & STD & 78.8 & 30.0 & 5.0 & 1.3 & 15.0 & 2.5 & 15.0 & 10.0 \\
6 & TD & 78.8 & 30.0 & 5.0 & 1.3 & 15.0 & 2.5 & 15.0 & 10.0 \\
7 & TSF & 78.8 & 30.0 & 10.0 & 1.3 & 7.5 & 5.0 & 15.0 & 10.0 \\
8 & KNW & 73.8 & 30.0 & 5.0 & 1.3 & 15.0 & 5.0 & 7.5 & 10.0 \\
9 & ES & 75.1 & 30.0 & 10.0 & 1.3 & 3.8 & 5.0 & 15.0 & 10.0 \\
\hline
\end{tabular}


Table 4. Recommendations and advice for each category of Potential Educational Use (PEU).

\begin{tabular}{ccccccccccccccc}
\hline Site- Nmb & Site Code & PEU & (V) & (A) & (UI) & (S) & (L) & (DP) & (Av) & (Sc) & (U) & (Oc) & (Dp) & (Gd) \\
\hline 1 & AS & 88.8 & 10.0 & 10.0 & 5.0 & 5.0 & 3.8 & 2.5 & 5.0 & 5.0 & 5.0 & 10.0 & 20.0 & 7.5 \\
2 & AC & 81.3 & 7.5 & 10.0 & 5.0 & 7.5 & 5.0 & 2.5 & 5.0 & 1.3 & 5.0 & 10.0 & 15.0 & 7.5 \\
3 & NL & 89.4 & 7.5 & 10.0 & 5.0 & 5.0 & 5.0 & 3.0 & 3.8 & 5.0 & 5.0 & 10.0 & 20.0 & 10.0 \\
4 & SD & 75.0 & 10.0 & 10.0 & 5.0 & 5.0 & 5.0 & 2.5 & 5.0 & 5.0 & 5.0 & 10.0 & 5.0 & 7.5 \\
5 & STD & 85.8 & 5.0 & 10.0 & 5.0 & 5.0 & 5.0 & 0.8 & 5.0 & 5.0 & 5.0 & 10.0 & 20.0 & 10.0 \\
6 & TD & 83.8 & 10.0 & 10.0 & 5.0 & 7.5 & 3.8 & 2.5 & 5.0 & 5.0 & 5.0 & 10.0 & 10.0 & 10.0 \\
7 & TSF & 79.0 & 7.5 & 10.0 & 5.0 & 7.5 & 5.0 & 0.2 & 5.0 & 1.3 & 5.0 & 10.0 & 15.0 & 7.5 \\
8 & KNW & 74.6 & 10.0 & 5.0 & 5.0 & 5.0 & 3.8 & 0.8 & 5.0 & 5.0 & 5.0 & 10.0 & 10.0 & 10.0 \\
9 & ES & 80.5 & 5.0 & 10.0 & 5.0 & 5.0 & 5.0 & 0.5 & 5.0 & 2.5 & 5.0 & 10.0 & 20.0 & 7.5 \\
\hline
\end{tabular}

Table 5. Recommendations and advice for each category of Potential Tourism Use (PTU).

\begin{tabular}{cccccccccccccccc}
\hline Site Nmb & Site Code & PTU & (V) & (A) & (UI) & (S) & (L) & (DP) & (Av) & (Sc) & (U) & (Oc) & (IP) & (El) & (Pr) \\
\hline 1 & AS & 86.4 & 10.0 & 10.0 & 5.0 & 5.0 & 3.8 & 2.5 & 5.0 & 15.0 & 10.0 & 5.0 & 10.0 & 1.3 & 3.8 \\
2 & AC & 77.5 & 7.5 & 10.0 & 5.0 & 7.5 & 5.0 & 2.5 & 5.0 & 7.5 & 5.0 & 5.0 & 10.0 & 2.5 & 5.0 \\
3 & NL & 86.4 & 7.5 & 10.0 & 5.0 & 5.0 & 5.0 & 3.8 & 3.8 & 15.0 & 10.0 & 5.0 & 10.0 & 1.3 & 5.0 \\
4 & SD & 82.6 & 10.0 & 10.0 & 5.0 & 5.0 & 5.0 & 2.5 & 5.0 & 15.0 & 10.0 & 5.0 & 5.0 & 1.3 & 3.8 \\
5 & STD & 85.1 & 5.0 & 10.0 & 5.0 & 5.0 & 5.0 & 3.8 & 5.0 & 15.0 & 10.0 & 5.0 & 10.0 & 1.3 & 5.0 \\
6 & TD & 75.1 & 10.0 & 10.0 & 5.0 & 7.5 & 3.8 & 2.5 & 5.0 & 7.5 & 10.0 & 5.0 & 5.0 & 1.3 & 2.5 \\
7 & TSF & 77.5 & 7.5 & 10.0 & 5.0 & 7.5 & 5.0 & 2.5 & 5.0 & 7.5 & 5.0 & 5.0 & 10.0 & 2.5 & 5.0 \\
8 & KNW & 80.2 & 10.0 & 5.0 & 5.0 & 5.0 & 3.8 & 3.8 & 5.0 & 15.0 & 10.0 & 5.0 & 7.5 & 1.3 & 3.8 \\
9 & ES & 73.8 & 5.0 & 10.0 & 5.0 & 5.0 & 5.0 & 2.5 & 5.0 & 7.5 & 10.0 & 5.0 & 10.0 & 1.3 & 2.5 \\
\hline
\end{tabular}

Table 6. Recommendations and advice for each category of Risk of Degradation (DR).

\begin{tabular}{cccccccc}
\hline Site $\mathbf{N m b}$ & Site Code & DR & $\mathbf{( D g )}$ & $\mathbf{( P a )}$ & $\mathbf{( L p )}$ & $\mathbf{( A c )}$ & $\mathbf{( D p p )}$ \\
\hline 1 & AS & 48.8 & 8.8 & 10.0 & 10.0 & 15.0 & 5.0 \\
2 & AC & 53.8 & 8.8 & 5.0 & 20.0 & 15.0 & 5.0 \\
3 & NL & 79.0 & 26.5 & 20.0 & 10.0 & 15.0 & 7.5 \\
4 & SD & 43.8 & 8.8 & 5.0 & 10.0 & 15.0 & 5.0 \\
5 & STD & 61.3 & 8.8 & 20.0 & 10.0 & 15.0 & 7.5 \\
6 & TD & 43.8 & 8.8 & 5.0 & 10.0 & 15.0 & 5.0 \\
7 & TSF & 53.8 & 8.8 & 5.0 & 20.0 & 15.0 & 5.0 \\
8 & KNW & 65.0 & 17.5 & 15.0 & 10.0 & 15.0 & 7.5 \\
9 & ES & 62.5 & 17.5 & 5.0 & 20.0 & 15.0 & 5.0 \\
\hline
\end{tabular}

Table 7. Detailed scoring of the nine sites of geological interest selected (SV, PEU, PTU and DR).

\begin{tabular}{ccccccc}
\hline Site Nombre & Site Name & Site Code & SV & PEU & PTU & DR \\
\hline 1 & Akhfennir Sinkhole & AS & 78.8 & 88.8 & 86.4 & 48.8 \\
\hline 2 & Akhfénir Cliff & AC & 78.8 & 81.3 & 77.5 & 53.8 \\
\hline 3 & Naïla Lagoon & NL & 80.0 & 89.4 & 86.4 & 79.0 \\
\hline 4 & Sand Dunes & SD & 72.5 & 75.0 & 82.6 & 43.8 \\
\hline 5 & Steady Dunes & STD & 78.8 & 85.8 & 85.1 & 61.3 \\
\hline 6 & Tenouchad Daya & TD & 78.8 & 83.8 & 75.1 & 43.8 \\
\hline 7 & Tazgha Salt Flats & TSF & 78.8 & 79.0 & 77.5 & 53.8 \\
\hline 8 & Khaoui Naàm Wadi & KNW & 73.8 & 74.6 & 80.2 & 65.0 \\
\hline 9 & Echguiguen Site & ES & 75.1 & 80.5 & 73.8 & 62.5 \\
\hline
\end{tabular}



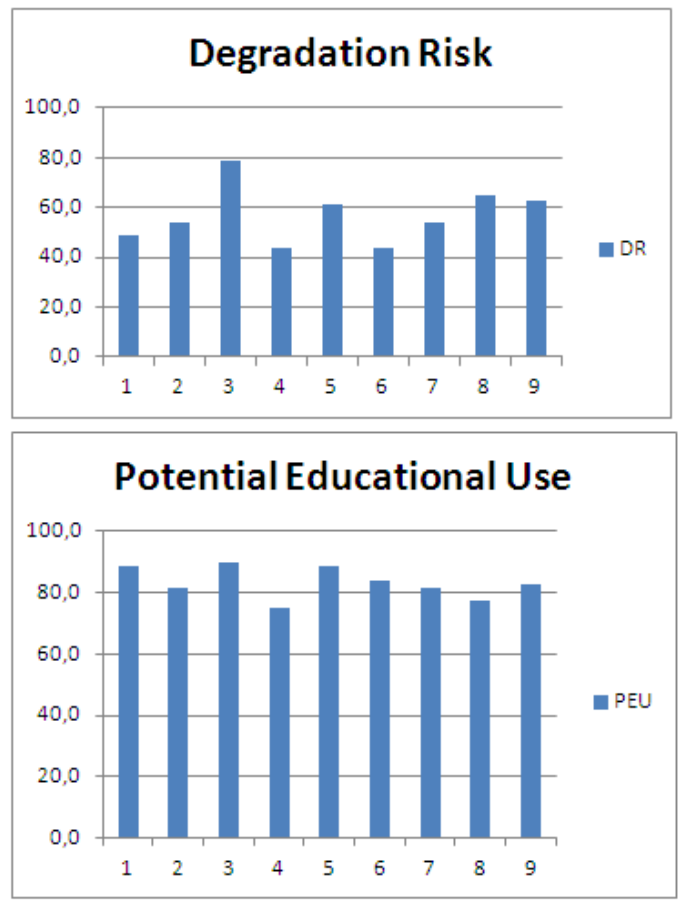
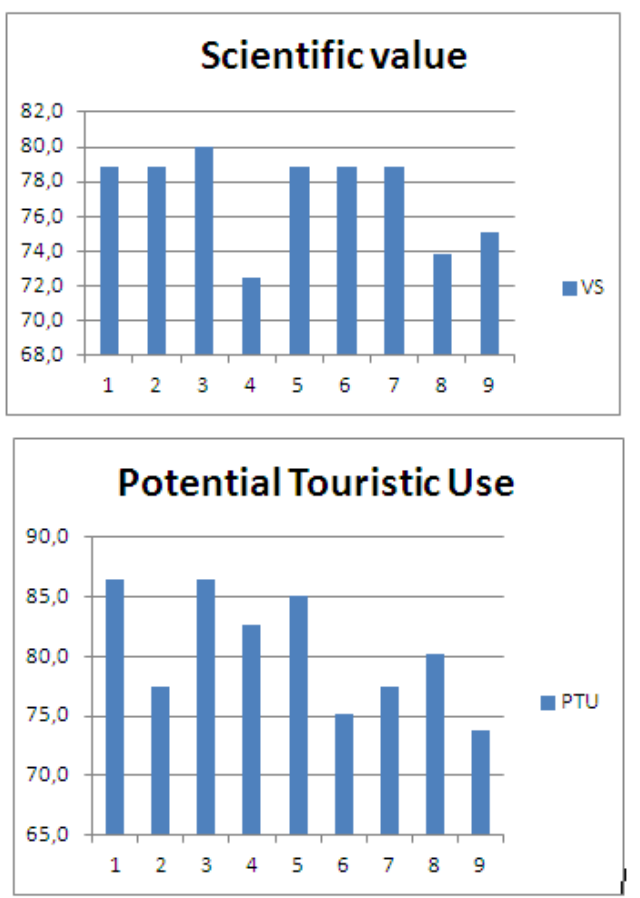

Figure 4. Histogram representation of the DR, SV, PEU, and PTU.

\section{Discussion}

The degradation processes of Khenifiss national park presents strong threats to important habitats (flora and fauna). However, care must be taken to prevent any disturbance that could, in the long term, affect its biological and heritage quality. The lagoon and its associated ecosystems represent the main heritage of Khenifiss national park, and it should be maintained in an optimum ecological state as much as possible. The Naïla lagoon, despite some number of constraints, remains the only lagoon at the national level in comparison with other atlantic and mediterranean lagoons, that is still wilderly natural [23].

The act of geoconservation must be understood as a static conception from a dynamic and innovative point of view, in which one seeks above all to safeguard a "geological identity and heritage" that generates some number of potentialities. Geoconservation will then become an act of coherence and consultation [43], capable of combining contradictory imperatives and promoting a vision and a message on the scale of future generations in order to guarantee real sustainability.

Geoconservation will be carried out as a coherent act of concerted action. It is capable of combining contradictory imperatives, promoting a vision, and drawing up a message for future generations in order to guarantee real sustainability.

This synthesis values the quality of the park's geosite and geodiversity, the sharing of geoconservation standards, best practices in geotourism development, the exchange of expertise, and support for geoheritage preservation $[44,45]$. Also, it makes possible to present the geosites with a notion of responsibility and, at the same time, to valorise the quality of the geodiversity of the selected ones. That is, the scientific, educational, and/or touristic value of the geological heritage is highlighted by the interest of geoconservation and the valorisation of geosites $[6,26]$. Besides, the risk of degradation of the selected geosites must also be quantified by the anthropogenic pressure and the effects of climate changes. Indeed, the result obtained will give the political and technical leaders of the park ways to prepare effective actions and strategies of geoconservation and geotourism enhancement [46,47].

The quantitative assessment carried out in the framework of the Khnefiss national park study provided nine inventoried sites. Calculations were made according to recent methodologies from the literature $[6,26,31]$. Standard thresholds were used in each part of the valuation $(0-25$ low, 
26-50 moderate, 51-75 high, 76-100 very high). The thresholds (low and moderate) were not found, and the high threshold is very noticeable among the proposed sites. Geosites (GS) and geodiversity (GD) were defined when a site of geological interest reached a scientific value, potential educational use, or potential touristic use value greater than 75 . The thresholds obtained are suggested for guidance (Table 1).

The quantitative approach used for the individual geosites confirmed the positive qualities attributed to the region. As a consequence, the scientific value obtained is very high in 6 of the proposed sites (Table 3; Figure 4). The potential educational use is very high in 7 sites, of which 3 cases have values of more than 85 (Table 4, Figure 4); while the potential touristic use is very high in 7 cases, which 3 cases have values greater than 85 (Table 5; Figure 4). On the other hand, the degradation risk was calculated as moderate or high in most cases (Table 6; Figure 4): it was moderate in 3 sites, high in 5 cases, and very high only in Naila lagoon (Table 7; Figure 4). These data prove that the geodiversity of the area is relevant enough to be used for scientific, educational, and/or tourism purposes, as well as for preservation plans (Table 8).

Table 8. Advising for each category (SV, PTU, PTE, and DR) according to the four thresholds (low, moderate, high, and very high).

\begin{tabular}{|c|c|c|c|c|}
\hline $\begin{array}{ll}\text { Category } & \text { Hresholds } \\
\end{array}$ & Low & Moderate & High & Very High \\
\hline Scientific value & Not applicable & Not applicable & $\begin{array}{l}\text { Echguiguen Site } \\
\text { Khaoui Naàm Wadi } \\
\text { Sand Dunes }\end{array}$ & $\begin{array}{c}\text { Naïla Lagoon } \\
\text { Akhfennir Sinkhole } \\
\text { Akhfénir Cliff } \\
\text { Steady Dunes } \\
\text { Tenouchad Daya } \\
\text { Tazgha Salt Flats }\end{array}$ \\
\hline Potential Educational Use & Not applicable & Not applicable & $\begin{array}{c}\text { Khaoui Naàm Wadi } \\
\text { Sand Dunes }\end{array}$ & $\begin{array}{c}\text { Naïla Lagoon } \\
\text { Akhfennir Sinkhole } \\
\text { Steady Dunes } \\
\text { Tenouchad Daya } \\
\text { Echguiguen Site } \\
\text { Akhfénir Cliff } \\
\text { Tazgha Salt Flats }\end{array}$ \\
\hline Potential Touristic Use & Not applicable & Not applicable & $\begin{array}{l}\text { Tenouchad Daya } \\
\text { Echguiguen Site }\end{array}$ & $\begin{array}{c}\text { Naïla Lagoon } \\
\text { Akhfennir Sinkhole } \\
\text { Steady Dunes } \\
\text { Tazgha Salt Flats } \\
\text { Sand Dunes } \\
\text { Khaoui Naàm Wadi } \\
\text { Akhfénir Cliff }\end{array}$ \\
\hline Degradation Risk & Not applicable & $\begin{array}{c}\text { Tenouchad Daya } \\
\text { Akhfénir } \\
\text { Cliff } \\
\text { Sand Dunes }\end{array}$ & $\begin{array}{l}\text { Khaoui Naàm Wadi } \\
\text { Echguiguen Site } \\
\text { Steady Dunes } \\
\text { Tazgha Salt Flats } \\
\text { Akhfennir Sinkhole }\end{array}$ & Naïla Lagoon \\
\hline
\end{tabular}

The result shows the priority given to the various actions of each programme according to four strategies: communication, environment to education, equipment, and management. It should be noted, however, that the execution of certain results is especially important for the implementation of the programme.

$>$ Communication strategy: This strategy aims to ensure the efficiency of communication tools. Below is a presentation of some principles [48] on which this orientation is based. These actions are:

Publication programme: The creation of a map guides [49], trail brochures, or leaflets as well as the website.

- The interpretation programme: equipment of the reception centre within Naiila lagoon.

$>$ Environment to Education Strategy: Because of the influence that children and young people can have on their family environment, their education is fundamental to improving environmental 
conditions and promoting substantial change [50]. The educational system is the most adequate structure for the implementation of extracurricular environmental education activities. These actions are:

0 The environmental education programme: the development of educational and teaching materials.

$\bigcirc \quad$ The training programme: a training of field staff in monitoring.

$>$ Equipment strategy: a strategy for the management of protected areas that aims to facilitate the contemplation and interpretation of a panoramic view or singular element of the landscape [51] in these actions are:

The equipment programme: The creation of an eco-museum is essential for the promotion of ecotourism and road and trail development.

The signage programme: all signage actions have priority for development.

$>$ Management strategy: a series of critical parameters have been selected for follow-up that are assessed using previously established indicators [52]. The methodology has been defined on the basis of the availability of personnel exclusively assigned to the collection of fundamental information, this being ensured by the guides and personnel in charge of monitoring or control, whose training is provided for in the corresponding programmes. The action is,

The management and maintenance programme: the elaboration of annual reports on the progress of the development programmes.

In addition to all these constraints, those related to unregulated tourism and tourism that is non-respectful of the environment are major constraints on the destruction and disruption (negative impacts) of the natural resources. Investment and marketing/promotion of the site is accessible and competitive, despite the serious damage caused by unstructured tourists, especially those who are heavy consumers and disruptive to landscapes and naturel resources. Thus, good management and preservation guarantee the development of geosite for the present and future generations and must be approached with great circumspection and insight.

The stated strategies have been translated into action programmes, which in turn have been translated into concrete projects or actions. The present work defines the strategies and programmes and establishes the criteria for the development of these projects and actions. It should be pointed out that although the relationship between strategies and actions is obvious, in some cases a project will materialise in accordance with the principles of geoconservation.

Finally, a SWOT analysis (Strengths, Weaknesses, Opportunities, and Threats) highlights Khnefiss national park's internal strengths and weaknesses in terms of geotourism development:

- The fragility of the most visited ecosystems in the absence of any preservation and safeguarding actions on the scale of the region.

- The risk of silting up and desertification without any measures to protect heritage, further accentuated by strong tourist pressure at Naïla lagoon.

- The consequent degradation of biodiversity and the threat of irreversible loss of certain components of this ecosystem.

- An exceptional natural site that requires the enhancement and protection of its geomorphosites according to the rules imposed by sustainable and responsible tourism.

Through this approach, the site calls on tourism stakeholders to make a real partnership effort with local authorities and communities for a responsible and participatory management for the development of sustainable tourism in the region. Actions are to be undertaken according to the founding principles of geotourism, which are to promote the most viable and sustainable development for the tourism industry in the park and its surroundings. 


\section{Conclusions}

The site of Khnefiss has undeniable qualities and values, both bio-ecological, geological, and cultural. However, the site faces many challenges due to large-scale human pressures. Since the site cannot be developed and managed independently of human pressure, much effort must be made to ensure some compatibility between conservation imperatives, the needs of the local population, and the requirements of tourists.

At the geosite, the stakes are geological, environmental and socioeconomic. The management of such a protected area implies a strong concertation and cooperation between local actors, touristic stakeholders and local population with collective awareness for rational management. In this way, the wealth enjoyed today will be passed on to future generations. In such a context, a more horizontal and participatory approach should be promoted.

On the other hand, the park's diversity of exceptional landscapes predisposes it to play an important role in geotourism, which must respect these geosites as well as the environment by a geoconservation strategy. In this sense, care must be taken to promote respectful geotourism in the park in general and in the lagoon of Nailla in particular. This new activity must not generate any disturbance to the natural environment. For this reason, a rigorous monitoring of this activity is necessary.

Finally, it is commonly accepted that no geoconservation and geoheritage action can be envisaged without participatory approaches and without the involvement of local population in the management and conservation of the natural resources. Awareness-raising is therefore a permanent component of the geoconservation strategy, and efforts are needed to ensure a certain compatibility between conservation imperatives and the basic needs of geotourism action.

Author Contributions: Data curation, S.M.; methodology, A.A.-S.-M.; resources, A.B.; writing—original draft, S.M. All authors have read and agreed to the published version of the manuscript.

Funding: This research received no external funding.

Acknowledgments: Authors would like to thank reviewers for their comments, suggestions, and notes, which significantly helped to improve the original version of the paper. The authors would like to thank Dmitry A. Ruban for his collaboration and availability.

Conflicts of Interest: The authors declare no conflict of interest.

\section{References}

1. Benkada, A.; Beloucgi, M.; lallouchen, A.; Essarsar, M. Regional financial governance: A lever for change for advanced regionalization in Morocco. Int. J. Sci. Eng. Res. 2018, 9, 74-79.

2. Ólafsdóttir, R. Geotourism. Geosciences 2019, 9, 48. [CrossRef]

3. Reynard, E.; Pica, A.; Coratza, P. Urban geomorphological heritage. An overview. In Quaestiones Geographicae; Bogucki Wydawnictwo Naukowe: Poznań, Poland, 2017; Volume 36, pp. 7-20.

4. Fahd, S.; Ater, M.; Pleguezuelos, J.-M.; Feriche, M.; Geniez, P. Herpetological diagnosis. Khnefiss GEF Programme of Protected Areas of Morocco; The High Commissioner for Water and Forests and the Fight against Desertification: Laàyoune, Morocco, 2006.

5. Lazzarini, M.; Aloia, A. Geoparks, Geoheritage and Geotourism: Opportunities and Tools in Sustainable Development of the Territory. Geo. J. Tour. Geosites. 2014, 13, 8-9.

6. Brilha, J. Inventory and Quantitative Assessment of Geosites and Geodiversity Sites: A review. Geoheritage 2016, 8, 119-134. [CrossRef]

7. Carcavilla, L.; Durán, J.J.; López-Martínez, J. Geodiversidad. Concepto y Relación con el Patrimonio Geológico. Geo. Temas 2008, 10, 1299-1303.

8. Carcavilla, L.; Durán, J.J.; Garcia-Cortés, A.; López-Martínez, J. Geological heritage and geoconservation in Spain: Past, present and future. Geoheritage 2009, 1, 75-91. [CrossRef]

9. Poiraud, A.; Dandurand, G. De la géoconservation au géotourisme: Un glissement de paradigme. Ann. De Géographie 2017, 717, 625-653. [CrossRef]

10. Duval, M.; Gauchon, C. Tourisme, géosciences et enjeux de territoires: Actualités du géotourisme. Téoros 2010, 29, 3-14. [CrossRef] 
11. Henriques, M.H.; Canales, M.L.; García-Frank, A.; Gomez-Heras, M. Accessible Geoparks in Iberia: A Challenge to Promote Geotourism and Education for Sustainable Development. Geoheritage 2019, 11, 471-484.

12. El Hadi, H.; Tahiri, A.; Brilha, J.; El Maidani, A.; Baghdad, B.; Zaidi, A. Geodiversity Examples of Morocco. From Inventory to Regional Geotourism Development. Open J. Ecol. 2015, 5, 409-419. [CrossRef]

13. Mirari, S.; Benmlih, A. The Sustainable Development of Oued Noun Oases through the Integration in the Biosphere Reserve Oasis of Southern Morocco. Int. J. Sci. Res. 2018, 7, 1211-1218.

14. Ibn Tattou, M. Khnefiss National Park. Vegetation Monitoring Programme. GEF Programme of Protected Areas of Morocco; The last report of High Commissioner for Water and Forests and the Fight against Desertification: Kenitra, Morocco, 2008.

15. Riser, J. Encyclopédie berbère, Gland-Hadjarien; Edisud: Biganos, France, 1999; pp. 3238-3243.

16. Elbelrhiti, H. Morphodynamique des Barkhanes Etude des Dunes du Sud-Ouest Marocain. Ph.D. Thesis, Paris Diderot University, Paris, France, 2005.

17. Idardare, Z.; Chiffoleau, J.-F.; Moukrim, A.; Ait Alla, A.; Auger, D.; Lefrere, L.; Rozuel, E. Metal concentrations in sediment and Nereis diversicolor in two Moroccan lagoons: Khnefiss and Oualidia. Chem. Ecol. 2008, 24, 329-340. [CrossRef]

18. Lefrere, L.; Ouassas, M.; Guillois, B.; Gillet, P.; Moukrim, A. Macrobenthic community structure of soft-bottom sediments in the Khnefiss lagoon, South of Morocco. Mater. Environ. Sci. 2015, 6, 2226-2236.

19. Lakhdar Idrissi, J.; Sarf, F.; El Mossaoui, N.; Orbi, A.; Hilmi, K. Étude pluridisciplinaire de la lagune de Khnefiss (Sud du Maroc). Rapp. Trav. Doc. 2000, 108, 114.

20. Mimouni, R.; Yacoubi, B.; Eddabra, R. Etude de la qualité microbiologique et physico-chimique de la lagune de Khnefiss. Rapp. Sci. Du Programme LagMar Maroc 2005, 1, 67-73.

21. Direction of the Park National of Khnefiss. Development and Management Plan (2013-2018); Census of the Park's fauna and flora: Laàyoune, Morocco, 2013.

22. Hafid, M.; Tari, G.; Bouhadioui, D.; Elmoussaid, I.; Echarfaoui, H.; Ait Salem, A.; Nahim, M.; Dakki, M. Atlantic Basins. In Continental Evolution: The Geology of Morocco; Michard, A., Saddiqi, O., Chalouan, A., Frizon de Lamotte, D., Eds.; Springer: Berlin, Germany, 2008; pp. 303-329.

23. Bendaanoun, M. Botanical Study and Ecological Analysis of the Vegetation of SIBE/Khnefiss National Park. GEF Project on Protected Areas-Morocco; The High Commissioner for Water and Forests and the Fight against Desertification: Laàyoune, Morocco, 2004.

24. Aboulabes, A. Thematic Diagnosis in Hydrogeology at the SIBE of Khnefiss. GEF Project on Protected Areas-Morocco; High Commissioner for Water and Forests and the Fight against Desertification: Laàyoune, Morocco, 2004.

25. Dakki, M.; Qninba, A.; El Agbani, M.A.; Bayed, A.; Fekhaoui, M. Fiche Descriptive sur les Zones Humides (FDR); Travaux de l'Institut Scientifique de Rabat: Rabat, Morocco, 2003; p. 11.

26. Aoulad-Sidi-Mhend, A.; Maaté, A.; Amri, L.; Hlila, R.; Chakiri, S.; Maaté, S.; Martín, M.M. The Geological Heritage of the Talassemtane National Park and the Ghomara coast Natural Area (NW of Morocco). Geoheritage 2019, 11, 1005-1025. [CrossRef]

27. Bruschi, V.M.; Cendrero, A. Direct and parametric methods for the assessment of geosites and geomorphosites. In Geomorphosites; Reynard, E., Coratza, P., Regolini-Bissig, G., Eds.; Verlag Dr. Friedrich Pfeil: München, Germany, 2009; pp. 73-88.

28. Reynard, E. The assessment of geomorphosites. In Geomorphosites; Reynard, E., Coratza, P., Regolini Bissig, G., Eds.; Verlag Dr. Friedrich Pfeil: Munchen, Germany, 2009; pp. 63-71.

29. Pereira, P.; Pereira, D.I. Methodological guidelines for geomorphosite assessment. Géomorphol. Relief Process. Environ. 2010, 16, 215-222. [CrossRef]

30. Bruschi, V.M.; Cendrero, A.; Albertos, J.A.C. A statistical approach to the validation and optimisation of geoheritage assessment procedures. Geoheritage 2011, 3, 131-149. [CrossRef]

31. Pereira, P.; Pereira, D.I. Assessment of geosites tourism value in geoparks: The example of Arouca Geopark (Portugal). In Proceedings of the 11th European Geoparks Conference, Arouca, Portugal, 19-21 September 2012; pp. 231-232.

32. Bollati, I.; Smiraglia, C.; Pelfini, M. Assessment and selection of geomorphosites and trails in the Miage Glacier area (Western Italian Alps). Environ. Manag. 2013, 51, 951-967. [CrossRef]

33. Bollati, I.; Crosa Lenz, B.; Zanoletti, E.; Pelfini, M. Geomorphological mapping for the valorization of the alpine environment. A methodological proposal tested in the Loana Valley (Sesia Val Grande Geopark, Western Italian Alps). J. Mt. Sci. 2017, 14, 1023-1038. [CrossRef] 
34. Fuentes-Gutiérrez, I.; Fernández-Martínez, E. Mapping geosites for geoheritage management: A methodological proposal for the regional park of Picos de Europa (León, Spain). Environ. Manag. 2012, 50, 789-806. [CrossRef] [PubMed]

35. Bergier, P.; Thévenot, M. Bibliographie ornithologique du Sahara Atlantique marocain-2. Go-South Bull. 2011, 8, 53-60.

36. Dakki, M.; de Ligny, W. The Khnefiss Lagoon and its Surrounding Environment (Province of La'youne, Morocco); Works Scientific Institute: Rabat, Morocco, 1988; p. 172.

37. Qninba, A.; El Agbani, M.A.; Benhoussa, A.; Rguibi Idrissi, H.; Thévenot, M. Ornithological Diagnosis. Khnefiss. GEF Programme of Protected Areas of Morocco; The High Commissioner for Water and Forests and the Fight against Desertification: Laàyoune, Morocco, 2005.

38. El Agbani, M.A.; Fekhaoui, M.; Bayed, A.; Schouten, J.R. The Khnefiss Lagoon and adjacent waters: Hydrology and hydrodynamics. In The Khnefiss Lagoon and Its Surrounding Environment (Province of Laàyoune, Morocco); Dakki, M., de Ligny, W., Eds.; Works Scientific Institute: Rabat, Morocco, 1988; pp. 17-26.

39. Agabi, C. Daya. In Encyclopédie Berbère 15|Daphnitae—Djado; Edisud: Biganos, France, 1995.

40. Zadane, Y.; Qninba, A.; Ibn Tattou, M.; Bergier, P. La daya de Ténouchad, un site de reproduction des Anatidés dans le Park National de Khnefiss. Go-South Bull. 2009, 6, 107-112.

41. Charioui, I.; Chikhaoui, M.; El Filali, M.F.; Abbassi, A.; Banaoui, A.; Kaaya, A. Production in Cell Biomass and Carotenoids under the Effect of a Saline Stress in Microalgae Dunaliella spp. isolated from Moroccan Saharian Saline. Int. J. Curr. Microbiol. Appl. Sci. 2017, 6, 8. [CrossRef]

42. Yves \& Christine Gauthier. Monuments à Alignement du Sahara Occidental et Leur Place Dans le Contexte Saharien. Available online: https://www.researchgate.net/publication/280383505_Monuments_a_alignement_ du_Sahara_occidental_et_leur_place_dans_le_contexte_saharien\#read (accessed on 26 August 2020).

43. Henriques, M.H.; Pena dos Reis, R.; Brilha, J.; Mota, T.S. Geoconservation as an emerging geoscience. Geoheritage 2011, 3, 117-128. [CrossRef]

44. Reynard, E.C. Geoheritage: Assessment, Protection and Management; Elsevier: Amsterdam, The Netherlands, 2018; pp. 1-450.

45. Gordon, J.E.; Crofts, R.; D’1az-Mart’inez, E. Geoheritage Conservation and Environmental Policies. In Geoheritage. Assessment, Protection, and Management; Reynard, E., Brilha, J., Eds.; Elsevier: Amsterdam, The Netherlands, 2018; pp. 213-235.

46. Paúl, C.M.; Gricelda, H.F.; Briones, J.; Caldevilla, P.; María, J.D.C.; Berrezueta, E. Geotourism and Local Development Based on Geological and Mining Sites Utilization, Zaruma-Portovelo, Ecuador. Geosciences 2018, 8, 205.

47. Brandolini, P.; Faccini, F.; Paliaga, G.; Piana, P. Urban geomorphology in coastal environment: Man-made morphological changes in a seaside tourist resort (Rapallo, Eastern Liguria, Italy). Quaest. Geogr. 2017, 36, 97-110. [CrossRef]

48. Tilden, F. Interpreting Our Heritage, 4th ed.; The University of North Carolina Press: Chapel Hill, NC, USA, 2007.

49. Bosak, K.; Boley, B.; Zaret, K. Deconstructing the 'Crown of the Continent': Power, politics and the process of creating National Geographic's Geotourism Mapguides. Tour. Geogr. 2010, 12, 460-480. [CrossRef]

50. Annette, V. Essentielle Convergence de Pensées Entre Écologie, Interprétation, Muséologie et Patrimoine. Available online: https://journals.openedition.org/ere/3706 (accessed on 26 August 2020).

51. Andalucia, J. Prorgama de uso Pùblico de Parque National de Talassemntane (Marreucos); Dirección del Parque Nacional de Talasamtan de Chefchaouen; Junta Andalucia y Alto Comisariado de Aguas y Bosques y Lucha contra la Desertificación del Reino de Marruecos: Laàyoune, Morocco, 2010.

52. Parks Canada Agency. National Park of Canada (Ivvavik) Management Plan. Available online: http: //parkscanadahistory.com/publications/ivvavik/mgt-plan-f-2007.pdf (accessed on 26 August 2020).

(C) 2020 by the authors. Licensee MDPI, Basel, Switzerland. This article is an open access article distributed under the terms and conditions of the Creative Commons Attribution (CC BY) license (http://creativecommons.org/licenses/by/4.0/). 